\title{
THE POWER TO PUNISH SUMMARILY FOR “DIRECT” CONTEMPT OF COURT: AN UNNECESSARY EXCEPTION TO DUE PROCESS
}

Contempt of courr is uniformly classified either as "indirect" or
"direct," and it is well recognized that a judge can punish the latter
without a formal hearing. This summary power to punish a "direct"
contempt is obviously offensive to the traditional values of a fair trial;

\footnotetext{
${ }^{1}$ A contempt is an act of willful disobedience, "calculated to embarrass, hinder, or obstruct the court in the administration of justice." Ex parte Holbrook, $133 \mathrm{Me}$. 276, 280, I77 Atl. 4I8, 420 (1935). Contempts are generally classified as criminal or civil. The former are subclassified as direct or indirect. Generally, crinninal contempt is committed against the majesty of the court, while a civil contempt is the failure to execute some order of the court issued in a civil suit, and is prosecuted by the opposing party. A direct contempt is one committed "in the presence of the court," in contrast to an indirect contempt which is committed "out of the presence of the court." In the case of an indirect contempt, however, an order to show cause must issue, and a separate hearing must be held. See Comments, 33 YALE L.J. 536 (r924); 21 Harv. L. Rev. i6r (rg08). See also Fox, The History of CONTEMPT of Court (1927) (wherein the author suggests that there was no historical right to a jury trial for contenpts in the face of the court; notwithstanding evidence to the contrary compiled by an early writer -Mr. Solly-Flood).

The power to punish summarily for contenpt has been repeatedly criticized. Offutt. v. United States, 348 U.S. II (1954); Cooke v. United States, 267 U.S. 517 (1925); Sacher v. United States, 343 U.S. $x, 22$ ( 1952 ) (dissenting opmion); Comments, 2 StAaN. L. REV. 763 (1950); 31 ColuM. L. REv. 956 (I93I); 37 HARV. L. REV. Ioxo (1924). Mr. Justice Black, dissenting in Sacher v. United States, supra at 22, said, "The historic power of summary contempt grew out of the need for judicial enforcement of order and decorum in the courtroom and to compel obedience to court orders. I believe the idea of judges having unrestricted power to by-pass the Bill of Rights in relation to criminal trials and punishments is an illegitimate offspring of this coercive contempt power. It has been said that a 'summary process of the Star Chamber slipped into the common law courts,' and that the alleged ancient history to support its existence is 'fiction." "

2 "Summary" has been held to refer to the method by which punishment is imposed, thus allowing a judge to sentence at the end of the trial, without notice and hearing. Sacher v. United States, 343 U.S. I (1952); criticized 37 CORNell L.Q. 795 (1952), 66 Harv. L. Rev. 170 (1952), 36 Minn. L. Rev, 965 (1952). Previously, it had been understood to mean the time and method in which punishment was imposed, requiring an imposition immediately upon the occurrence of the contemptuous act. Cooke v. United States, 267 U.S. $5 \times 7$ ( 1925 ). Perhaps the Supreme Court returned to the rationale of the Cooke case in Offutt v. United States, 348 U.S. II (1954). See note 19 infra.

${ }^{3}$ Powell v. Alabama, 287 U.S. 45,68 (1932): "It has never been doubted by this court, or any other so far as we know, that notice and hearing are preliminary steps essential to the passing of an enforceable judgment, and that they, together with a legally
} 
but, on the other hand, it is said to be essential to the preservation of those very values which it offends. ${ }^{4}$ For, since fairness in the administration of justice can be guaranteed only to the extent that a court can maintain order, dignity, and impartiality in its proceedings, the summary contempt power is defended as a measure necessary for preserving this proper decorum. ${ }^{5}$

In seeking to confine the exercise of this power within the limits of its rationale, the courts have settled upon the phrase "in the presence of the court," or some variant thereof, ${ }^{6}$ to define contemptuous conduct

competent tribunal leaving jurisdiction of the case, constitute basic elements of the constitutional requirements of due process of law"; Tumey v. Ohio, 273 U.S. 510,522 (1927): "That officers acting in a judicial or quasi-judicial capacity are disqualified by their interest in the controversy to be decided is, of course, the general rule"; Rochin v. California, 342 U.S. 165, 169 (1952); Mullane v. Central Hanover Bank and Trust Co., 339 U.S. 306,310 (1950).

"E.g., Cooke v. United States, 267 U.S. 517, 534 (1925): "To preserve order in the courtroom for the proper conduct of business, the court must act instantly to suppress disturbance or violence or physical obstruction or disrespect to the court when occurring in open court. There is no need of evidence or assistance of counsel before punishment, because the court has seen the offense. Such summary vindication of the court's dignity and authority is necessary . . . and the punishment imposed is due process of law", Ext parte Robinson, 85 U.S. ( 99 Wall.) 505, 510 (1873) ("... essential to the preservation of order"); Anderson v. Dunn, 5 U.S. (6 Wheat.) 61 (1821): "Courts of justice are universally acknowledged to be vested, by their very creation, with power to impose silence, respect, and decorum"; In re Cooper, 32 Vt. 253, 257 (1 859) (". . . implied, because it is necessary to the exercise of all other powers"); In re Oliver, 333 U.S. 257, 274 (1948) (dictum): "This Court held [in Ex parte Terry, 128 U.S. 289 (1888)] that under such circumstances a judge has power to punish an offender at once, without notice and hearing, although his conduct may also be punishable as a criminal offense. This Court reached its decision because it believed that a court's business could not be conducted unless it could suppress disturbances within the courtrom by immediate punishment." See also cases cited in note 5 infra.

5Offutt v. United States, 348 U.S. II (1954); Sacher v. United States, 343 U.S. I (1952); Ex parte Terry, 128 U.S. 289 (1888); Ex parte Poulson, I9 Fed. Cas. 1205, No. 11350 (1835); Weldon v. State, 150 Ark. 407, 234 S.W. 466 (1921); People ex rel. Field v. Turner, 1 Cal. 152 (1850); State v. Winthrop, 148 Wash. 526, 269 Pac. 793 (1928). See also Comment, 37 HARv. L. REv. 1oro, 1023 (1924), and cases cited in note 4 supra. As to the congressional power to deal with contempts, see Marshall v. Gordon, 243 U.S. 521, 54I (1917): "[T] implication that the right has been given to do that which is essential to the execution of some other and substantive authority expressly conferred. . . . Hence, it rests solely upon the right of self-preservation to enable the public powers to be exerted. . . [W] think from the very nature of that power that it is clear that it does not embrace punishment for contempt as punishment. ..."; Anderson v. Dunn, 5 U.S. (6 Wheat.) 61,69 (1821) ("the least possible power adequate to the end proposed").

${ }^{6}$ Nye v. United States, 313 U.S. 33 (1941); Ex parte Poulson, I9 Fed. Cas. 1205, No. I1 350 ( 1835 ) ("so near the presence of the court as to obstruct the administration 
which can be termed "direct"-and hence summarily punishable. This phrase, in addition, recognizes that, in fairness to the accused, only a judge who could observe the contemptuous nature of the conduct in open court should be invested with this power. ${ }^{7}$ Having adopted this short-hand formula, some courts have, however, ignored the broader considerations to which the phrase was intended to give expression and, by an uncritical application, have rationalized the imposition of summary punishment in exactly the type of situation which it was designed to exclude. ${ }^{8}$

of justice"); Cooke v. United States, 267 U.S. 517 (1925) ("in open court"); Savin, Petitioner, I3 I U.S. 267 (I889); Ex parte Clark, 208 Mo. I2 1, 106 S.W. 990 (1907) ("presence of the court"); People ex rel. Field v. Turner, I Cal. I52 (1850) ("in its presence"); In re Wood, 82 Mich. 75, 45 N.W. III3 (189o) ("the immediate view and presence"); FED. R. CRIM. P. 42 (a) ("actual presence"); 4 BLACKstone, CommenTARIES 286 (I 6 th ed. I825) ("face of the court").

${ }^{7}$ See Cooke v. United States, 267 U.S. 517,536 (1925): 'Punishment without issue or trial was so contrary to the usual and ordinarily indispensible hearing before judgment, constituting due process, that the assumption that the court saw everything that went on in open court was required to justify the exception. . ." In re Wood, 82 Mich. 75, 82, 45 N.W. III3, III5 (1890): ". . . contempts not committed in (the court's) immediate view and presence must be brought before the court by affidavit of the persons who witnessed them, or have knowledge of them. ..." Cf. In re Oliver, 333 U.S. 257,272 (1948) (dictum): "This Court said that knowledge acquired from the testimony of others, or even from the confession of the accused, would not justify conviction without a trial in which there was an opportunity for defense." Savin, Petitioner, I3I U.S. 267, 277 (1889); Nelles, The Summary Pozver to Punish for Contempt, 3 I ColuM. L. REv. 956 (193I); Frankfurter and Landis, Power of Congress Over Procedure in Criminal Contempts in "Inferior" Federal Courts-A Study in Separation of Powvers, 37 HARv. L. Rev. 1010 (1924).

${ }^{8}$ Nye v. United States, 313 U.S. 33,48 (1940): "The question is whether the words 'so near thereto' have a geographical or a causal connotation. Read in their context and in the light of their ordinary meaning, we conclude that they are to be construed as geographical terms." Savin, Petitioner, I3 1 U.S. 267, 277 (I889) (attempted bribery in a witness waiting room): "We are of opinion that, within the meaning of the statuie, the court, at least when in session, is present in every part of the place set apart for its own use, and for the use of its officers, jurors and witnesses; and misbehavior anywhere in such place is misbehavior in the presence of the court." In Weldon $v$. State, 150 Ark. 407,234 S.W. 466 (1921), defendant in a pending case attacked the judge at a beach resort. The imposition of summary punishment by that judge for contempt was affirmed on the ground that the assault occurred in the "constructive presence" of the court. Cf. State . Goff, 88 S.E.2d 788 (S.C. 1955), where an assault committed on the back steps of the courthouse, while the court was in recess and the jury retired to consider a verdict, was held a direct contempt, since the court was "present" throughout the building in which it sat. In United States v. Shipp, 203 U.S. 563 (1906) (on demurrer), 2 I4 U.S. 386 (1909) (on the merits), a Negro was lynched on the day his appeal froin a rape conviction had been granted by the United States Supreme Court. The Court exercised original jurisdiction to "punish summarily" the sheriff and the leaders of the mob. 
Illustrative is the recent case of Lyons v. Superior Court, ${ }^{0}$ where the question presented was whether petitioner's tardiness, when he was sole counsel for defendant in a felony proceeding, was a "direct" contempt of court, for which he could be sentenced summarily to the county jail. In affirming the trial court's summary punishment, the majority reasoned that the tardiness was such a participation in the trial as to be within the immediate view and presence of the court and that it tended to obstruct the administration of justice. ${ }^{10}$

Since the court could observe the fact that petitioner was absent, there is no surface difficulty in concluding that the absence occurred "in the presence of the court."11 But, clearly, only inexcusable tardiness is contemptuous, ${ }^{12}$ and the lack of an excuse would be an element essential to petitioner's contempt conviction. Inasmuch as the court had no firsthand knowledge as to whether the contempt was excusable, then only by a mechanical application of the "formula" could it conclude that the contempt was "direct" and summarily punishable. Furthermore, it is evident that the obstruction to the administration of justice, which had already occurred, could hardly be redressed by imposing summary punishment; nor could the dignity of the court be vindicated any better in a summary than in a plenary proceeding.

This latter observation raises the broader question as to whether there actually are any situations in which the summary contempt power is necessary to accomplish the ends which purportedly justify its use. It is suggested that the reasoning advanced to sustain this power often

${ }^{8} 43$ Cal.2d 755, 278 P.2d 68I (x955).

${ }^{10}$ Petitioner offered illness as an excuse for his tardiness of thirty-five minutes. The court declined to believe this excuse, noting that petitioner had been habitually tardy. Compare In re McHugh, 152 Mich. 505, 116 N.W. 459 (1908), where the court held that an attorney's voluntary offer of a defense in a summary proceeding constituted a waiver of his right to a later plenary trial. If the courts are to hold that a contemnor, in offering an explanation or excuse in such cases, waives his right to notice and hearing, attorneys will certaintly be discouraged from offering any defense, even thought it might be substantial. Such a practice would seem undesirable, in view of the probability that most contempt situations are cleared up by explanation and apology.

${ }^{11}$ But see the language of the court in Ex parte Clark, 208 Mo. 121, 148, $106 \mathrm{~S} . \mathrm{W}$. 990, 997 (1907): "It would seem like an exquisite and palpable contradiction of terms to complain in one breath that the petitioner and his acts were absent, and in the next breath to say that such absence constituted a presence. ..."

${ }^{12}$ See Ex parte Clark, Id. at $x 48$, 106 S.W. at 997 : "The absence of an attorney, ... from the court room at the precise time due there may be susceptible of many innocent explanations. ... [N] one of these explanations are within the mere eyesight or earshot of any court of ordinary mortal endowments." Muffly v. State, 129 Neb. 334, 261 N.W. 560 (1935); Wise v. Commonwealth, 97 Va. 779, 34 S.E. 453 (1899). 
fails to distinguish between punishment which is sufficient to remove an obstruction to the administration of justice, or to vindicate the dignity of the court, and punishment which is necessary to accomplish these purposes. ${ }^{13}$ Indeed, if the test of necessity is applied to the various situations in which the power has been invoked, the apparent conclusion is that it has no justification at all. ${ }^{14}$ Consider, for example, the clearest case-a calculated disturbance in the courtroom, intended by its perpetrator not only to obstruct the proceeding, but to insult the court. Instead of punishing the offender summarily, the judge could order him arrested immediately and charged with the crime of contempt. The obstruction to the administration of justice would thereby be removed; and the vindication of the dignity of the court could be postponed to a separate hearing.

At least one commentator has maintained that the summary contempt power should continue to be tolerated as a petty power to deal with petty offenses..$^{15}$ To this it might be answered that, if the offenses are petty, they should not justify an exception to constitutional procedural rights. ${ }^{16}$ The only basis for such an exception is not expediency, but necessity; and, absent a necessity, the exception should fail. ${ }^{17}$

${ }^{13}$ It is recognized that the summary contempt power exists as an exception to principles of due process. Myers v. United States, 264 U.S. 95, 104-05 (1924); Sacher v. United States, 343 U.S. I, 36 (1952); Blackmer v. Umited States, 284 U.S. 42 I, 440 (1932). Therefore it would seem that the "necessity" which justifies such a sui generis power must be a strict necessity-not merely an expedieucy. Marshall v. Gordon, 243 U.S. 521,543 (1917) (reasoning that the power rests "solely" upon "the right of self-preservation"); Anderson v. Dunn, 5 U.S. (6 Wheat.) 6I (182I).

${ }^{14}$ See I COMPLETE WORKS OF EDWARd Livingston ON CRIMINAL JURISPRUdence 258-267 ( 1873 ). Mr. Livingston contends that the "plea of necessity" should be limited to the power to remove obstructions to the courts' orderly processes aud does not justify the existence of summary power to punish for contempt. He points out that in this one area, a judge holds all three governmental functions-to define, prosecute and punish such offenses. Since judges are only human, he urges that all contempts should be statutorily defined as criminal offenses and punishable only in accordance with this defined law. Degrees of contempt would be recognized and the offender would, therefore, be dealt with according to the nature of his offense. If an attorney were charged with coutempt during a trial, the hearing on this charge could be deferred until the end of the trial.

${ }^{15}$ Nelles, op. cit. supra note 7.

${ }^{10}$ Comment, 33 YALE L.J. 536 (1924) (if the puuishment is inflicted to deter others, then it is purely penal in character, and the alleged contemnor should be afforded the protections granted a defendant in a criminal trial).

${ }^{17}$ Marshall v. Gordon, 243 U.S. 52I, 54I (1917): "[W]e think from the very nature of that power it is clear that it does not embrace punishment for contempt as punishment, since it rests only upon the right of self-preservation. ..." See note 13 stipra. 
Reconsideration by the courts of a power so discordant with due process is always timely, though its existence has long been asserted. At the present, there is some indication that reconsideration is taking place and may eventually lead to the complete abolition of this power. ${ }^{18}$ It is submitted that such an abolition would be consistent with the efficient administration of justice and would better accord with the requirements of a fair trial.

Paul V. Evans

${ }^{18}$ Due process of law requires notice and hearing before an impartial tribunal. See note 3 supra. In Offutt $v$. United States, 348 U.S. II (1954), the Court, relying on Cooke v. United States, 267 U.S. 517 (1925), held that when a judge becomes personally "embroiled" with an attorney during a trial, fairness requires that the offended judge may not impose summary punishment, but instead another judge must hear the contempt proceeding. The result is to grant the accused a full, plenary hearing, under the holding of the Cooke case, supra. Having taken this first step, so soon after the decision in Sacher $v$. United States, 343 U.S. 1 (1952), see note 2 supra, the present Court may well eventually take the second, completely abolishing summary punishment. 